\title{
Bacteriological Studies on Salmonella Isolated from Balady Chicken Meat
}

Eid H. M.*, Helal I. M. and Radwa H. Kouta

Bacteriology, Immunology and Mycology Department, Fac. Vet. Med. Suez Canal University, *Animal Health research institute Port-Said branch, ARC.

\section{Abstract}

Two hundred freshly slaughtered of balady chicken samples were collected aseptically from markets in Port-Said city during the period from September 2016 to September 2018. Nine Salmonella isolates (4.5\%) were isolated and therefore serologically identified. The isolated Salmonellae were Salmonella Typhimurium 2/9 (22.2\%) and Salmonella Muenster 2/9 (22.2\%) which was the most frequent identified. Other serotypes as Salmonella Enteritidis 1/9 (11.1\%), Salmonella Blegdam 1/9 (11.1\%), Salmonella Anatum 1/9 (11.1\%), Salmonella Lamberhurst 1/9 (11.1\%) and Salmonella Ayinde 1/9 (11.1\%) were also identified. The antibiogram revealed highly resistant to Ery thromycin and Oxytetracycline by a percentage (100\%) followed by Nalidixic acid (44.4\%) while it was highly sensitive to Chloramphenicol and Ciprofloxacin by a percentage (100\%) followed by Gentamycin (88.9\%). Polymerase Chain Reaction detected the virulence genes (stn, $\operatorname{sop} \mathbf{B}, \boldsymbol{s p v} \mathbf{C}$ and $\boldsymbol{b c f C})$ genes were positive in all tested Salmonella serotypes 7/7 (100\%) while (avrA) gene was positive in 6/7 (85.7\%) of tested Salmonella serotypes.

Key words: Salmonella- chicken- PCR- Antibiogram sensitivityPort-Said.

\section{Introduction}

Salmonella is a cause of foodborne illness worldwide with an estimated annual economic loss about 3.7 billion dollars United States Department of Agriculture (2015). Salmonellosis was considered as an important public health problem which causes high morbidity on poultry and human. The main clinical signs of salmonellosis in human are (typhoid) enteric fever and gastroenteritis so enteric fever is a systemic illness which results from $S$. Typhi and $S$. Paratyphi Pegues and Miller (2000). Over use of antimicrobial agents in poultry for prophylaxis, treatment purposes and growth promotion got a major antimicrobial resistance and so multidrug resistance, which are 
observed among many serovars of Salmonella Duong et al. (2006). Polymerase Chain Reaction (PCR) is a method to investigate outbreaks of foodborne and identification of pathogens Riyaz et al. (2004) while PCR is high specific, give fast results and less timeconsuming than cultural technique. PCR technique considered as a rapid diagnostic tool for detection of Salmonella in food.

Therefore, this work was observed for isolation and identification of Salmonella from chicken meat, serotyping, study antimicrobial sensitivity of Salmonella isolates and screens the presence of virulence genes (stn, $\operatorname{sop} \mathrm{B}, \operatorname{spv} \mathrm{C}, \quad b c f \mathrm{C}$ and $\operatorname{avr} \mathbf{A})$ in the isolated serotypes by using PCR method.

\section{Material and Methods}

A total of 200 freshly slaughtered balady chicken samples collected aseptically from markets in PortSaid city since September 2016 to September 2018 , the collected samples were from chicken breast and then subjected for bacteriological examination.

- Isolation and identification of Salmonella isolates

Twenty-five grams of the test samples were added aseptically to $225 \mathrm{ml}$ buffered peptone water then incubated at $37^{\circ} \mathrm{C}$ for 18 hours after that enriched on
Rappaport-Vassiliadis soya broth by incubation at $41.5^{\circ} \mathrm{C}$ / 24 hours. Enriched samples were streaked on Xylose lysine deoxycholate agar and Hekton enteric agar and incubated at $37{ }^{\circ} \mathrm{C} / 24 \mathrm{hrs}$ Oxoid (1998). Suspected colonies were purified on nutrient agar, biochemically identified by triple sugar iron agar, urea hydrolysis test, lysine decarboxylation test, indole production test, citrate utilization test and oxidase test Oxoid (1998). Auto-agglutination test was made for biochemically positive isolates, then serological confirmation by poly $\mathrm{O}$ and poly $\mathrm{H}$ antisera ISO 6579 (2002).

\section{- Antimicrobial susceptibility testing}

By using disc diffusion technique Finegold and Martin (1982) and isolates were classified as sensitive, intermediate and resistant according to $\boldsymbol{C L S \boldsymbol { I }}$ (2011).

\section{- PCR of Salmonella serotypes}

For detection of the different virulence genes in Salmonella serotypes (Table 1 and Table 2) were performed according to Sambrook et al. (1989).

\section{Results And Discussion}

The prevalence of Salmonella in chicken samples was 9/200 $(4.5 \%)$ as shown in Table (3) which is nearly the same result with Adelino et al. (2018) who detected Salmonella in 3/850 
(3.7\%) in chicken samples from Brazil. The results on this study are higher than the reports of FSAI (2004) who detected 245 $(3.2 \%)$ Salmonella isolates in Ireland from 7,616 raw poultry meats samples. On the other hand, the results on this study was lower than Dhary (2019) who surveyed the prevalence of Salmonella in retail outlets was $16 / 225 \quad(7.1 \%)$ and Elkenany et al. (2019) who isolated Salmonella from chicken samples 50/170 (29.4\%) in Egypt.

Variations in the prevalence of Salmonella from chicken meat in many studies could be due to the differences in type and number of samples, sensitivity of detection methods, time of sampling and storage conditions. Salmonella isolates were serotyped in this study into Salmonella Typhimurium 2/9 (22.2\%) and Salmonella Muenster 2/9 (22.2\%) which was the most frequent identified. Other serotypes as Salmonella Enteritidis

(11.1\%), Salmonella Blegdam 1/9 (11.1\%), Salmonella Anatum 1/9 (11.1\%), Salmonella Lamberhurst 1/9 (11.1\%) and Salmonella Ayinde 1/9 (11.1\%) were also identified as shown in Table (4). These results nearly the same result with Hee et al. (2007) who detected Salmonella Typhimurium 15/64 (23.4\%) which was the most common serotype in broiler chicken isolates. These results were higher than Narapati (2007) who isolated Salmonella Typhimurium 8/52 (15.38\%). While it was lower than Chaiba et al. (2008) who isolated Salmonella Typhimurium (40.35\%) from chicken samples at markets as the most frequent serotype isolated out of 57 Salmonella isolates in Morocco.

According to the results concerning antimicrobial susceptibility tests in Table (5), Salmonella isolates showed high resistance to Erythromycin and Oxytetracycline by a percentage (100\%) followed by Nalidixic acid (44.4\%) while it was highly sensitive to Chloramphenicol and Ciprofloxacin by a percentage $(100 \%)$ followed by Gentamycin $(88.9 \%)$, Colistin (77.8\%) and finally Ceftoxin and Trimethoprim+Sulfamethaxzole by a percentage $(66.7 \%)$ for each which is in agreement with Martha et al. (2006) who observed all tested Salmonella Enteritidis strains showed resistance to Erythromycin and Tetracycline 80/80 (100\%). These results were disagreed with Ulaya et al. (2012) who showed that, Salmonella Enteritidis revealed sensitivity to Amoxicillin (95.7\%), Tetracycline (82.6\%) and Gentamicin (17.4\%). 
In present study 7 Salmonella serotypes were examined by PCR for determination the

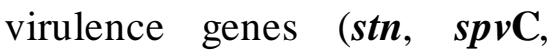
$\operatorname{sop} \mathbf{B}, \boldsymbol{b c f} \mathbf{C}$ and $\boldsymbol{a v r} \mathrm{A})$ as shown in Table (6). We found stn and sopB genes were positive in all tested serotypes $7 / 7(100 \%)$ as shown in Figure (1) which is parallel with Vivek et al. (2015) who observed that, Salmonella Typhimurium and Salmonella Enteritidis were positive in stn gene and Prager et al. (1995) who showed $S$. Typhimurium and $S$. Enteritidis were found to carry stn gene. $s p v \mathbf{C}$ gene was positive in all tested serotypes $7 / 7(100 \%)$ as shown in Figure (2) and $\boldsymbol{b} \boldsymbol{c f} \mathbf{C}$ gene was positive in all tested Salmonella isolates $7 / 7(100 \%)$ as shown in Figure (3) while avrA present in $6 / 7$ $(85.7 \%)$ of the isolated Salmonella which is present in all Salmonella serotypes except Salmonella Lamberhurst as shown in Figure (4) and it is in agreement with Borges et al. (2013) who showed avrA gene present in $100 \%$ in Salmonella Enteritidis strains.

Table (1): Oligonucleotide primers sequences:

\begin{tabular}{|c|c|c|c|}
\hline Primer & Sequence & $\begin{array}{l}\text { Amplified } \\
\text { product }\end{array}$ & Reference \\
\hline \multirow[t]{2}{*}{ stn } & TTG TGT CGC TAT CAC TGG CAA CC & \multirow[t]{2}{*}{$617 \mathrm{bp}$} & \multirow{2}{*}{$\begin{array}{c}\text { Murugkar et al } \\
(2003)\end{array}$} \\
\hline & ATT CGT AAC CCG CTC TCG TCC & & \\
\hline \multirow[t]{2}{*}{ avrA } & CCT GTA TTG TTG AGC GTC TGG & \multirow[t]{2}{*}{$422 \mathrm{bp}$} & \multirow{8}{*}{$\begin{array}{c}\text { Huehn et al. } \\
\quad(2010)\end{array}$} \\
\hline & AGA AGA GCT TCG TTG AAT GTC C & & \\
\hline \multirow[t]{2}{*}{$\operatorname{sop} B$} & tca gaa gRc gtc taa cca ctc & \multirow[t]{2}{*}{$517 \mathrm{bp}$} & \\
\hline & tac cgt cet cat gca cac tc & & \\
\hline \multirow[t]{2}{*}{$b c f \mathrm{C}$} & acc aga gac att gec ttc c & \multirow[t]{2}{*}{$467 \mathrm{bp}$} & \\
\hline & ttc tgc tcg $\operatorname{ccg} \operatorname{cta} t$ tc $g$ & & \\
\hline \multirow[t]{2}{*}{$s p v \mathrm{C}$} & acc aga gac att gec ttc c & \multirow[t]{2}{*}{$467 \mathrm{bp}$} & \\
\hline & ttc tga tcg $\operatorname{ccg}$ cta ttc g & & \\
\hline
\end{tabular}

Table (2): Cycling conditions of the different primers for virulence genes during PCR:

\begin{tabular}{|c|c|c|c|c|c|c|}
\hline Gene & $\begin{array}{c}\text { Primary } \\
\text { denaturation }\end{array}$ & $\begin{array}{c}\text { Secondary } \\
\text { denaturation }\end{array}$ & Annealing & Extension & $\begin{array}{c}\text { No. of } \\
\text { cycles }\end{array}$ & $\begin{array}{c}\text { Final } \\
\text { extension }\end{array}$ \\
\hline stn & $94^{\circ} \mathrm{C}$ & $94^{\circ} \mathrm{C}$ & $59^{\circ} \mathrm{C}$ & $72^{\circ} \mathrm{C}$ & 35 & $72^{\circ} \mathrm{C}$ \\
& $5 \mathrm{~min}$. & $30 \mathrm{sec}$. & $40 \mathrm{sec}$. & $45 \mathrm{sec}$. & & $10 \mathrm{~min}$. \\
\hline avr A & $94^{\circ} \mathrm{C}$ & $94^{\circ} \mathrm{C}$ & $58^{\circ} \mathrm{C}$ & $72^{\circ} \mathrm{C}$ & 35 & $72^{\circ} \mathrm{C}$ \\
& $5 \mathrm{~min}$. & $30 \mathrm{sec}$. & $40 \mathrm{sec}$. & $45 \mathrm{sec}$. & & $10 \mathrm{~min}$. \\
\hline sop B & $94^{\circ} \mathrm{C}$ & $94^{\circ} \mathrm{C}$ & $58^{\circ} \mathrm{C}$ & $72^{\circ} \mathrm{C}$ & 35 & $72^{\circ} \mathrm{C}$ \\
& $5 \mathrm{~min}$. & $30 \mathrm{sec}$. & $40 \mathrm{sec}$. & $45 \mathrm{sec}$. & & $10 \mathrm{~min}$. \\
\hline bcf C & $94^{\circ} \mathrm{C}$ & $94^{\circ} \mathrm{C}$ & $53^{\circ} \mathrm{C}$ & $72^{\circ} \mathrm{C}$ & 35 & $72^{\circ} \mathrm{C}$ \\
& $5 \mathrm{~min}$. & $30 \mathrm{sec}$. & $40 \mathrm{sec}$. & $45 \mathrm{sec}$. & & $10 \mathrm{~min}$. \\
\hline spv C & $94^{\circ} \mathrm{C}$ & $94^{\circ} \mathrm{C}$ & $58^{\circ} \mathrm{C}$ & $72^{\circ} \mathrm{C}$ & 35 & $72^{\circ} \mathrm{C}$ \\
& $5 \mathrm{~min}$. & $30 \mathrm{sec}$. & $40 \mathrm{sec}$. & $45 \mathrm{sec}$. & & $10 \mathrm{~min}$. \\
\hline
\end{tabular}


Table (3) Number and percentage of of Salmonella isolates:

\begin{tabular}{|c|c|c|}
\hline \multirow{2}{*}{$\begin{array}{c}\text { Total number of chicken samples } \\
(\mathbf{n})\end{array}$} & \multicolumn{2}{|c|}{ Salmonella isolates } \\
\cline { 2 - 3 } & Number & $\%$ \\
\hline 200 & 9 & 4.5 \\
\hline
\end{tabular}

Table (4): Number and percentage of different serotypes of the isolated Salmonella from chicken samples $n=9$ :

\begin{tabular}{|c|c|c|}
\hline Serotype & $\begin{array}{c}\text { Number of } \\
\text { isolates }\end{array}$ & \% of Salmonella serotypes \\
\hline S. Typhimurium & 2 & 22.2 \\
\hline S. Enteritidis & 1 & 11.1 \\
\hline S. Blegdam & 1 & 11.1 \\
\hline S. Anatum & 1 & 11.1 \\
\hline S. Muenster & 2 & 22.2 \\
\hline S. Lamberhurst & 1 & 11.1 \\
\hline S. Ayinde & 1 & 11.1 \\
\hline Total no. & 9 & 100 \\
\hline
\end{tabular}

Table (5): Number and percentage of Salmonella serotypes exhibiting resistance and sensitivity to various antimicrobial agents $(n=9)$ :

\begin{tabular}{|c|c|c|c|c|c|c|}
\hline \multirow[t]{2}{*}{ Antimicrobial agents } & \multicolumn{2}{|c|}{$\begin{array}{c}\text { Sensitive } \\
\text { Salmonella } \\
\text { isolates }\end{array}$} & \multicolumn{2}{|c|}{ Intermediate } & \multicolumn{2}{|c|}{$\begin{array}{c}\text { Resistant } \\
\text { Salmonella } \\
\text { isolates }\end{array}$} \\
\hline & No & $\%$ & No & $\%$ & No & $\%$ \\
\hline Levofloxacine $(5 \mu \mathrm{g})$ & 5 & 55.6 & 1 & 11.1 & 3 & 33.3 \\
\hline Amoxicillin (10 $\mu \mathrm{g})$ & 2 & 22.2 & 4 & 44.4 & 3 & 33.3 \\
\hline Cefotaxim $(30 \mu g)$ & 6 & 66.7 & 1 & 11.1 & 2 & 22.2 \\
\hline Chloramphnicol $(30 \mu g)$ & 9 & 100 & 0 & 0 & 0 & 0 \\
\hline Colistin $(10 \mu \mathrm{g})$ & 7 & 77.8 & 0 & 0 & 2 & 22.2 \\
\hline Erythromycin $(15 \mu \mathrm{g})$ & 0 & 0 & 0 & 0 & 9 & 100 \\
\hline Gentamycin $(10 \mu \mathrm{g})$ & 8 & 88.9 & 1 & 11.1 & 0 & 0 \\
\hline Nalidixic acid ( $30 \mu \mathrm{g}$ ) & 5 & 55.6 & 0 & 0 & 4 & 44.4 \\
\hline Ciprofloxacin $(5 \mu g)$ & 9 & 100 & 0 & 0 & 0 & 0 \\
\hline Oxytetracycline $(30 \mu \mathrm{g})$ & 0 & 0 & 0 & 0 & 9 & 100 \\
\hline $\begin{array}{c}\text { Trimethoprim+Sulfamethaxzole } \\
(1.25+23.75 \mu \mathrm{g})\end{array}$ & 6 & 66.7 & 1 & 11.1 & 2 & 22.2 \\
\hline
\end{tabular}


Table (6): Results of Polymerase Chain Reaction technique for different virulence genes of Salmonella serotypes:

\begin{tabular}{|c|c|c|c|c|c|}
\hline \multirow{2}{*}{ Sample } & \multicolumn{5}{|c|}{ Results } \\
\cline { 2 - 6 } & stn & spvC & sop B & bcfC & avrA \\
\hline S. Typhimurium & + & + & + & + & + \\
\hline S. Enteritidis & + & + & + & + & + \\
\hline S. Blegdam & + & + & + & + & + \\
\hline S. Anatum & + & + & + & + & + \\
\hline S. Muenster & + & + & + & + & + \\
\hline S. Lamberhurst & + & + & + & + & - \\
\hline S. Ayinde & + & + & + & + & + \\
\hline
\end{tabular}

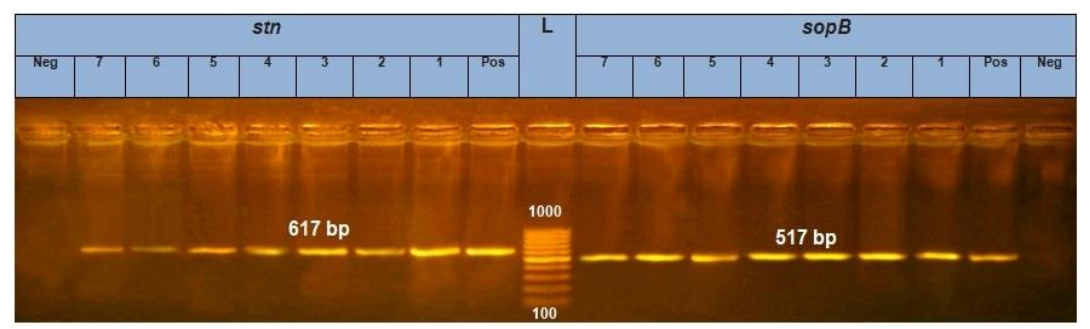

Figure (1): PCR of (stn) and (sop B) in Salmonella serotypes:

Primer set for genes (stn and sopB) (617 bp and $517 \mathrm{bp}$ ) respectively. $\mathrm{Neg}=$ negative control*, Pos=positive control* and L= ladder $(100$ $1000 \mathrm{bp}$ ). All lanes showed positive results: Lane (1): $S$. Typhimurium, Lane (2): $S$. Enteritidis, Lane (3): $S$. Blegdam, Lane (4): $S$. Anatum, Lane (5): $S$. Muenster, Lane (6): $S$. Lamberhurst and Lane (7): $S$. Ayinde.

*(Positive and or negative controls were represented by field sample that were previously confirmed to be positive or negative by PCR for the related genes in the Reference laboratory for veterinary quality control on poultry production, Animal health research institute).

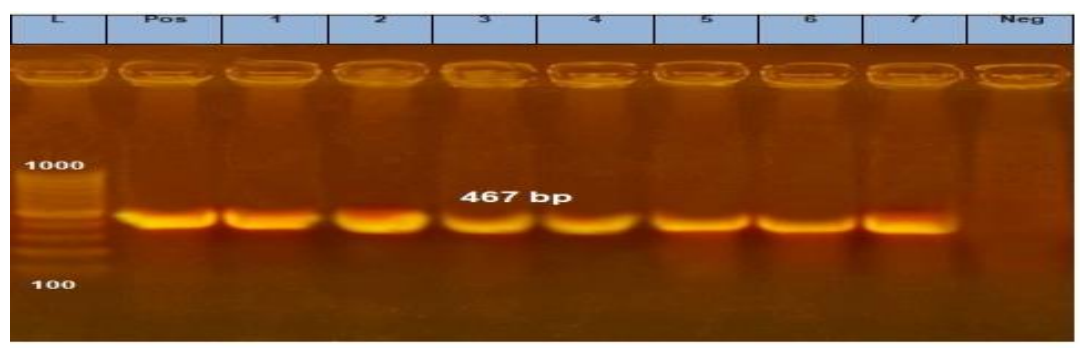

Figure (2): PCR of (spvC) in Salmonella serotypes:

Primer set for spvC gene (467 bp). Neg= negative control*, Pos=positive control* and $\mathrm{L}=$ ladder $(100-1000 \mathrm{bp})$. All lanes showed positive results: Lane (1): $S$. Typhimurium, Lane (2): $S$. Enteritidis, 
Lane (3): $S$. Blegdam, Lane (4): $S$. Anatum, Lane (5): $S$. Muenster, Lane (6): $S$. Lamberhurst and Lane (7): $S$. Ayinde.

*(Positive and or negative controls were represented by field sample that were previously confirmed to be positive or negative by PCR for the related genes in the Reference laboratory for veterinary quality control on poultry production, Animal health research institute).

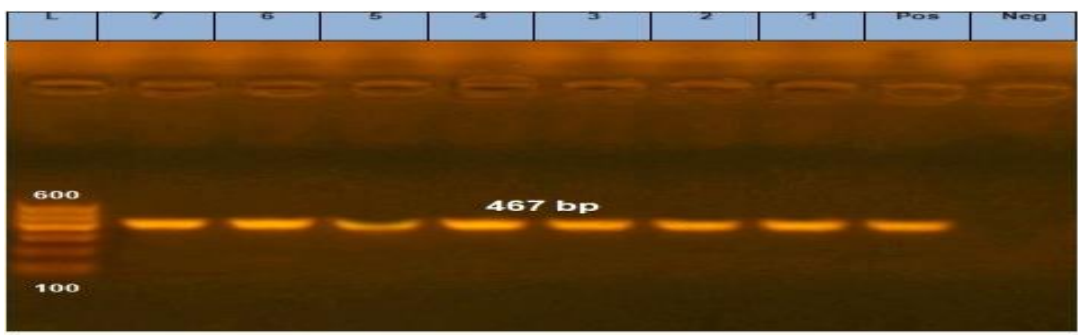

Figure (3): PCR of $(b c f C)$ in Salmonella serotypes:

Primer set for $\boldsymbol{b} \boldsymbol{c} \boldsymbol{f C}$ gene $(467 \mathrm{bp})$. $\mathrm{Neg}=$ negative control*, Pos=positive control* and $\mathrm{L}=$ ladder (100-600 bp). All lanes showed positive results: Lane (1): $S$. Typhimurium, Lane (2): $S$. Enteritidis, Lane (3): $S$. Blegdam, Lane (4): $S$. Anatum, Lane (5): $S$. Muenster, Lane (6): $S$. Lamberhurst and Lane (7): $S$. Ayinde.

*(Positive and or negative controls were represented by field sample that were previously confirmed to be positive or negative by PCR for the related genes in the Reference laboratory for veterinary quality control on poultry production, Animal health research institute).

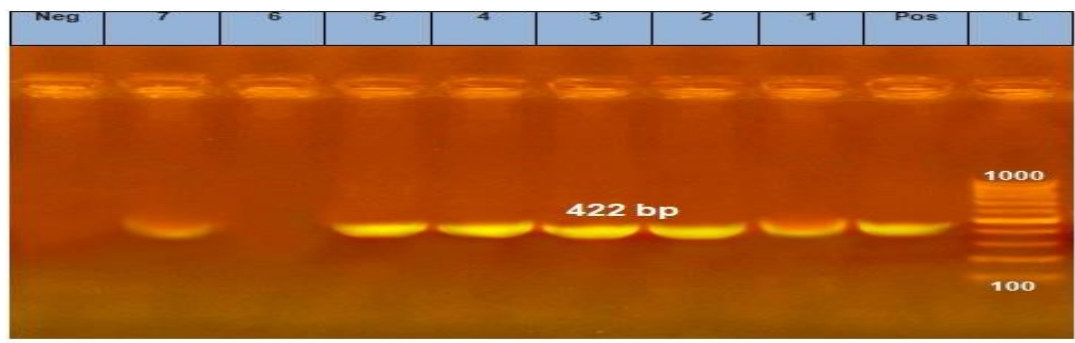

Figure (4): PCR of (avrA) in Salmonella serotypes:

Primer set for avrA gene (422 bp). Neg= negative control*, Pos=positive control* and L= ladder (100-1000 bp). Lanes (1-2-3-4-57) showed positive results and lane (6) $S$. Lamberhurst showed negative result.

*(Positive and or negative controls were represented by field sample that were previously confirmed to be positive or negative by PCR for the related genes in the Reference laboratory for veterinary quality control on poultry production, Animal health research institute). 


\section{Conclusion}

Salmonellosis is very important public health problem which has a negative effect on human health all over the world. Antibiogram considered an important tool to detect the proper antibacterial which should be used in treatment of salmonellosis and must be know the antimicrobial sensitivity to Salmonella to prevent the random use of antibiotic in poultry treatment and so to avoid the occurrence of antibiotic resistance. PCR is a good rapid tool for detection the virulence genes in pathogenic bacteria

\section{References}

Adelino, d. C. N., Larrayane, A. C., Ricardo, C.T. C., Dália, d. P. R., Sergio, B. M., Eduardo, E. d. S. F., Carlos, A. C. J. (2018): Salmonella isolated from chicken carcasses from a slaughterhouse in the state of Mato Grosso, Brazil: antibiotic resistance profile, serotyping, and characterization by repetitive sequence-based PCR system. Poultry Science. Vol. 97, Pp. 1373-1381. https://doi.org/10.3382/ps/pex406.

Borges, K. A., Furian, T. Q., Borsoi, A., Moraes, H. L. S., Salle, C. T. P., Nascimento, V. P. (2013): Detection of virulence-associated genes in Salmonella Enteritidis isolates from chicken in Southern Brazil. Pesquisa Veterinária Brasileira. 33(12), 1416-1422.

Chaiba, A., Rhazi, F. F., Abdelkader, C., Soulaymani, B. R., Zerhouni, M. (2008): Occurrence of Salmonella in Chicken Carcasses and Giblets in Meknes-Morocco. Pakistan Journal of Nutrition, Pp. 231-233. DOI: 10.3923/pjn.2008.

CLSI (Clinical and Laboratory Standards Institute) (2011): Performance standards for antimicrobial susceptibility testing; twenty first informational supplements, 1-172.

Dhary, A. A. (2019): Occurrence and antimicrobial susceptibility of Salmonella isolates from grilled chicken meat sold at retail outlets in Erbil City, Kurdistan region, Iraq. Ital. J Food Saf. 8(2), 8233.

Duong, V. N., Paulsen, P., Suriyasathaporn, W., Smulders, F. J., Kyule, M. N., Baumann, M. P. et al. (2006): Preliminary analysis of tetracycline residues in marketed pork in Hanoi, Vietnam. Annals of the New York Academy of Sciences. 1081, 534-542.

Elkenany, R., Elsayed, M. M., Zakaria, A. I., El-Sayed, S. A., Rizk, M. A. (2019): Antimicrobial resistance profiles and virulence genotyping of Salmonella enterica serovars recovered from broiler 
chickens and chicken carcasses in Egypt. BMC veterinary research. 15(1), 124. doi:10.1186/s12917-019-1867-z.

Finegold, S. M. and Martin, W. J. (1982): Diagnostic microbiology. $6^{\text {th }}$ Ed., the C.V. Mosby Company, St. Louis, Toronto, London.

FSAI (Food Safety Authority of Ireland) (2004): Report on Zoonoses in Ireland. Dublin, 1-46.

Hee, J. C., Yeon, J. L., In, S. H., Sae, Y. K., Hye, W. C., Joon, Y. S., Jun, M. K., Yong, H. P., Ji-Hun, J., Woo, J. K. (2007): Characteristics of non-typhoidal Salmonella isolates from human and broiler chickens in Southwestern Seoul, Korea. J Korean Med Sci. 22(5), 773-778. doi: $10.3346 / \mathrm{jkms} .2007 .22 .5 .773$.

Huehn, S., La Ragione, R. M., Anjum, M., Saunders, M., Woodward, M. J., Bunge, C., Helmuth, R., Hauser, E., Guerra, B., Beutlich, J., Brisabois, A., Peters, T., Svensson, L., Madajczak, G., Litrup, E., Imre, A., Herrera-Leon, S., Mevius, D., Newell, D. G., Malorny, B. (2010): Virulotyping and antimicrobial resistance typing of Salmonella enterica serovars relevant to human health in Europe. Foodborne Pathogens Dis 2010.7, 523-35.

ISO 6579 (International Organization for standardization) (2002): Microbiology of food and animal feeding stuffs. Horizontal methods for the detection of Salmonella species (4th ed.).

Martha, O. C., Aldemir, R. R., Luciana, R. d. S., Fernando, P., Hamilton, L. S. d. M., Carlos, T. P. S., Silvio, L. d. S. R., Vladimir, P. d. N. (2006): Antibiotic resistance in Salmonella Enteritidis isolated from broiler carcasses. Brazilian Journal of Microbiology. 37, 368 371. https://doi.org/10.1590/S1517-83822006000300030.

Murugkar, H. V., Rahman, H., Dutta, P. K. (2003): Distribution of virulence genes in Salmonella serovars isolated from man and animals. Indian J Med Res. 117, 66-70.

Narapati, D. (2007): Prevalence and Antimicrobial Resistance of Salmonella in imported chicken carcasses in Bhutan. Chiang Mai University and Freie Universitat Berlin, Pp. 1-92.

Oxoid, (1998): The oxoid manual of culture media.8th Ed. Oxoid, Limited, Basingstoke, Hampshire, England.

Pegues, D. and Miller, S. I. (2000): Salmonella species including Salmonella Typhi. In GL Mandell, JE Bennett \& R. Dolin (Eds.), Principles and Practice of Infectious Diseases (7th ed., Vol. 2): Elsevier Inc. 
Prager, R., Fruth, A., Tschäpe, H. (1995): Salmonella enterotoxin (stn) gene is prevalent among strains of Salmonella Enterica, but not among Salmonella bongori and other Enterobacteriaceae. FEMS Immunol Med Microbiol. 12(1), 47-50.

Riyaz-Ul-Hassan, S., Verma, V., Qazi, G. N. (2004): Rapid detection of Salmonella by polymerase chain reaction. Mol Cell Probes. 18, 333-339.

Sambrook, J., Fritscgh, E. F., Mentiates (1989): Molecular coloning. A laboratory manual. Vol !., Cold spring Harbor Laboratotry press, New York.

Ulaya, W., Hang'ombe, M., Zulu, V., Nalubamba, K., Mulenga, E., Isogai, H., Isogai, E. (2012): Distribution of virulence genes and antimicrobial susceptibility of Salmonella isolated from dogs and chickens in Zambia. IJAVMS, Vol. 6, Issue 5, 2012, 360-367. DOI: 10.5455/ijavms.170 Research Article.

USDA (United States Department of Agriculture) (2015): Economic Research Service. Available from: $\mathrm{http} / / / \mathrm{www} . e r s . u s d a . g o v /$ data-products/chartgallery/detail.aspx? chartId=50500. Accessed on 25-04-2016.

Vivek, K. N., Sanjay, S., Anil, P., Nitin, E. G. (2015): Detection of virulence genes in Salmonella Species isolated from chevon and chicken meat. Journal of Animal Research. Vol. 5, No 1, Pp. 115-118.

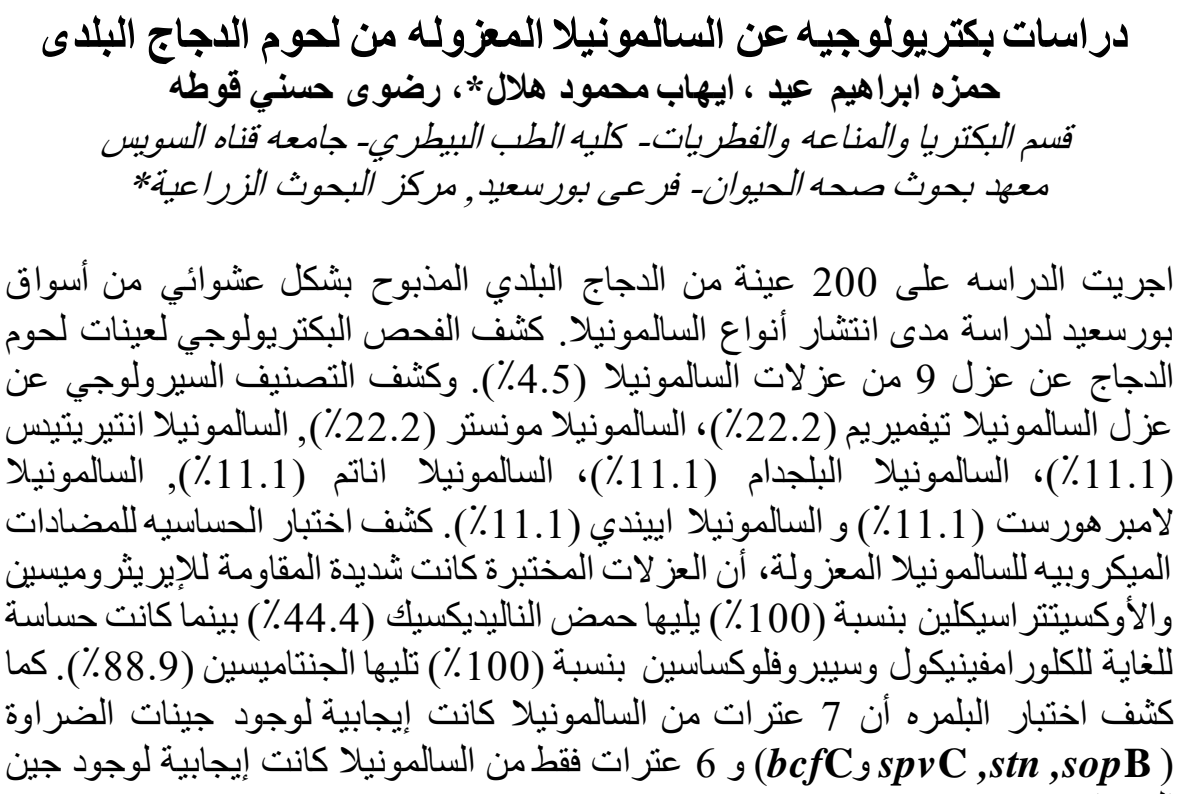

الضراوة (avrA). 